remember being irritated by tutors telling me to 'go home and read about it yourself' and so I try to support my students while still trying to encourage them to be self directed.

I accept that just before examinations students will often switch to a surface approach $^{6}$ in their learning, I try to encourage students to take a deep approach and to understand what they are doing and to try to work from principles. I do think that reward often stimulates learning; the reward can vary from student to student whether it is passing an exam, getting a job or simply learning for one's own enjoyment. I am conscious that I have always been very competitive and I make great efforts to ensure that I do not stray too far into a Socratic method ${ }^{11}$ and risk humiliating my students.

\section{Tara George}

\section{REFERENCES}

1. Cantillon P, Wood D, Hutchinson L. ABC of learning and teaching in medicine. London: BMJ Publishing Group, 2003.

2. Grasha A. Teaching with style: a practical guide to enhancing learning by understanding learning and teaching styles. New York, NY: Alliance Publishers, 1996.

3. Phillips DC and Soltis JF. Perspectives on learning. New York: Teachers College Press, 1985.

4. Montauk S and Grasha A. Adult HIV outpatient care: A handbook for clinical teaching. Cincinnati, $\mathrm{OH}$ : University Of Cincinnati, 1993.

5. Bandura A. Social foundations of thought and action: a social cognitive theory. Englewood Cliffs, NJ: Prentice Hall, 1986.

6. Biggs J. Handbook of educational ideas and practices. London and New York, NY: Routledge, 1990.

7. Knowles MS. Andragogy in action: applying modern principles of adult learning. San Francisco, CA: JosseyBass, 1984.

8. Hirsch ED. The knowledge core curriculum — what's behind its success? Educational Leadership 1993; 50(8): 23-25.

9. Schon DA. Educating the reflective practitioner: towards a new design for teaching and learning in the profession. San Francisco, CA: Jossey-Bass, 1987.

10. Boud D. Developing student autonomy in learning. London: Kogan Page, 1988.

11. Vaughn L, Baker R. Teaching in the medical setting: balancing teaching styles, learning styles and teaching methods. Medical Teacher 2001; 23(6): 610-612.

12. Dember W. The new look in motivation. American Scientist 1965; 53, 409-427.

13. Kolb DA, Fry R. Towards an applied theory of experiential learning. In: Cooper LD (ed). Theories of Group Processes. London: John Wiley, 1975.

DOI: 10.3399/bjgp09X472999

\title{
Maike Fitzpatrick
}

\section{Diagnostic delusions}

One of the few bright moments for Labour politicians slouching grimly towards electoral doom at this year's party conference was the announcement that GPs will soon be able to refer suspected cancer patients for key diagnostic tests within 1 week. This initiative was applauded by delegates, acclaimed by the Guardian ('could save up to 10000 lives a year') and welcomed by cancer charities. The president of the Royal College of General Practitioners hailed it 'one of the most important breakthroughs' for GPs, claiming that it represented 'a major vote of confidence in the ability and professionalism of GPs who for too long have been dismissed as the poor relations of our specialist colleagues'.?

But does early diagnosis confer a better prognosis? According to the National Awareness and Early Diagnosis Initiative (NAEDI), 'we have known for years that, in general, the earlier cancer is diagnosed and treated, the greater are the chances of a successful outcome'. ${ }^{3}$ However, we soon learn that we 'know' this in the same way that generations of doctors 'knew' that bleeding and cupping and purging were effective therapies. 'With the exception of breast cancer', the promoters of the early diagnosis initiative admit, 'there is no solid evidence for the actual effect of delay on survival in cancer'.

But who needs 'solid' evidence of an 'actual' effect when the power of wishful thinking can unite desperate politicians and credulous journalists, medical entrepreneurs, and a fearful public? Another NAEDI bulletin reports how the headline figures of preventable deaths are derived. 'Drawing on processes of elimination and extrapolation', (the magic of statistics!), Mike Richards (the government's cancer 'Tsar') 'presented his personal view that advanced stage at diagnosis is likely to account for at least $50-75 \%$ of avoidable cancer deaths'. ${ }^{4}$ 'Likely'? 'At least'? '50-75\%'? Why not $100 \%$ - or $0 \%$ ? But we mustn't be pernickety because 'this equates to something like 4000-7500 unnecessary deaths each year'. Yet it seems that a few earlier scans arranged by GPs can save 10000 lives - even more than are being 'unnecessarily' lost. We seem to have entered 'something like' a parallel universe.

Professor Richards may be right that some cancer patients would live for longer if they were diagnosed earlier. But the personal conviction of even such a distinguished oncologist cannot be regarded as a satisfactory basis for a major national programme. It is not only that the benefits of such an initiative need to be demonstrated, but the potential harms should also be recognised.

Although the NAEDI bulletin claims that, exceptionally, there is some evidence for the benefit of early diagnosis of breast cancer, there is also evidence of the adverse effects of mammographic screening (particularly in terms of overdiagnosis and overtreatment). ${ }^{5}$ There is controversy only over the proportion of women who experience unnecessary surgery, radiotherapy, and chemotherapy as a result of mammography (and the number is certain to be increased as a result of another popular announcement at Brighton - Gordon Brown's promise to reduce the age of eligibility for breast screening).

The notion that GPs will be 'empowered' by being enabled to order investigations is illusory. We are already becoming mere agents endorsing demands for recreational screening tests. Nor can the problem for the public be reduced to that of the 'worried well'. The quest for early diagnosis inexorably transforms every citizen into a potential patient. This will not improve health, still less enable people to achieve that even more elusive goal of government policy, 'wellbeing'.

\section{REFERENCES}

1. Stratton A. Gordon Brown to woo conference with cancer pledge and new NHS cash. Guardian, 2009; 26 Sep:

http://www.guardian.co.uk/politics/2009/sep/26/gord on-brown-conference-cancer-nhs (accessed 6 Oct 2009).

2. Ellis O. GPs are to refer suspected cancer patients for tests in a week under new scheme. BMJ 2009; 339: b3994.

3. Forman D, Sara Hiom. Review of the evidence base. National Awareness and Early Diagnosis Initiative, Newsletter 2008; 1(1): 3 .

4. Anonymous. Keynote Speech: 'The Size of the Prize' National Awareness and Early Diagnosis Initiative, Newsletter 2008; 2(1): 3 .

5. Fitzpatrick M. Sense about mammography. Br J Gen Pract 2009; 59(561): 297.

DOI: 10.3399/bjgp09X473006 